\author{
${ }^{1}$ A.M. Alimzhanov ${ }^{(i D)},{ }^{2}$ K.Zh. Shetiyeva \\ ${ }^{1}$ Dr. Sci. (Phys.-Math.), Prof., E-mail: Aivarmr@rambler.ru \\ ${ }^{2} \mathrm{PhD}$ student, E-mail: karlygash.shetiyeva@gmail.com \\ Al-Farabi Kazakh National University, Almaty, Kazakhstan
}

\title{
RESEARCH OF THE STRESS STATE OF AN ELEMENT OF A THICK-WALL PIPELINE UNDER CONDITIONS OF POWER AND CORROSION EFFECT
}

The stress state of an element of a thick-walled pipeline is studied under conditions of power and corrosion effect in the statement of plane deformation. The material of the element under the influence of external loads goes into an elastic-plastic state. The corrosive effect of the pumped medium leads to softening of the material in the plastic zone. This softening of the material is taken into account by a special inhomogeneity function in the Tresca-Saint-Venant plasticity condition. The elastic-plastic problem in the axisymmetric setting (uniform pressure) and non-axisymmetric setting (non-uniform external pressure along the contour) is considered. The problem is solved by the method of sharing static and physical equations for the considered elastoplastic material and the perturbation method in the theory of an elastoplastic body. An assessment of the strength and bearing capacity of a thick-walled element under corrosive force effect is given.

Key words: thick-wall element, elastoplastic state, corrosion damage to the material, plastic inhomogeneity, softening function.

\author{
${ }^{1}$ А.М. Алимжанов, ${ }^{2}$ Қ.Ж. Шетиева \\ ${ }^{1}$ ф.-м.,ғ.д., проф., E-mail: aivarmr@rambler.ru \\ ${ }^{2} \mathrm{PhD}$ докторант, E-mail: karlygash.shetiyeva@gmail.com \\ әл-Фараби атындағы Қазақ ұлттқ университеті, Алматы қ, Қазақстан \\ Қалың қабырғалы құбыр элементінің күштік және коррозиялық әсер ету \\ жағдайларында кернеулі күйін зерттеу
}

Жазық деформация қойылымында күштік және коррозиялық әсер ету жағдайларында қалың қабырғалы құбыр элементінің кернеулі күйі зерттелді. Сыртқы жүктемелердің әсерінен элемент материалы серпімді-иілгіш күйге өтеді. Айдалатын ортаның коррозиялық әсері иілгіш аймақта материалдың жұмсаруына әкеледі. Материалдың жұмсаруы ТрескСен-Венанның иілгіштік шартында біртексіздіктің арнайы функциясымен ескеріледі. Осесимметриялы қойылымда (бірқалыпты қысым) және симметриялы емес қойылымда (контуры бойынша бірқалыпты емес сыртқы қысым) серпімді иілгіш есеп қарастырылды. Есеп қарастырылып отырған серпімді иілгіш материал үшін статикалық және физикалық теңдеулерді бірлесіп пайдалану әдісімен және серпімді иілгіш дене теориясында ұйытқулар әдісімен шешілді. Коррозиялық-күштік әсер ету жағдайында қалың қабырғалы элементтің беріктігі мен көтергіштік қабілеттілігіне баға берілді.

Түйін сөздер: қалың қабырғалы элемент, серпімді иілгіш күй, материалдың коррозиялық зақымдануы, иілгіштік біртексіздік, беріктендіру функциясы.

\footnotetext{
${ }^{1}$ А.М. Алимжанов, ${ }^{2}$ К.Ж. Шетиева

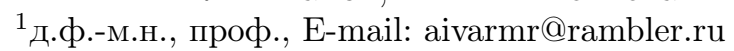

${ }^{2} \mathrm{PhD}$ докторант, E-mail: karlygash.shetiyeva@gmail.com

Казахский национальный университет им. аль-Фараби, г. Алматы, Казахстан

Исследование напряженного состояния элемента толстостенного трубопровода в условиях силового и коррозионного воздействия
} 
Исследовано напряженное состояние элемента толстостенного трубопровода в условиях силового и коррозионного воздействия в постановке плоской деформации. Материал элемента под действием внешних нагрузок переходит в упругопластическое состояние. Коррозионное воздействие перекачиваемой среды приводит к разупрочнению материала в пластической зоне. Это разупрочнение материала учитывается специальной функцией неоднородности в условии пластичности Треска-Сен-Венана. Рассмотрена упругопластическая задача в осесимметричной постановке (равномерное давление) и неосесимметричной постановке (неравномерное по контуру наружное давление). Задача решена методом совместного использования статических и физических уравнений для рассматриваемого упругопластического материала и методом возмущений в теории упругопластического тела. Дана оценка прочности и несущей способности толстостенного элемента при коррозионно-силовом воздействии.

Ключевые слова: толстостенный элемент, упругопластическое состояние, коррозионные повреждения материала, пластическая неоднородность, функция разупрочнения.

\section{Introduction}

According the normative documents [1,2] in engineering practice, when calculating, as a rule, elastically deformable elements of pipelines are considered. At the same time, with an increase in external loads, the material of a thick-walled element passes into an elastoplastic state. Most pipelines are operated with prolonged exposure under increased loads in aggressive work environments. The corrosive effect of an aggressive pumped medium leads to damage and microcracking of the material during operation. In the plastic zone, as a result of corrosionforce action, a softening of the element occurs, which leads to a significant decrease in its strength and bearing capacity. The danger of exposure to aggressive media on the material working under load is due to the fact that in such cases the pipelines fail in a very short time, sometimes even with accidents. In this regard, this work is devoted to the study of the stress-strain state, strength and load-bearing capacity of the elastic-plastic element of a thick-walled pipeline under conditions of force and corrosion, which leads to the material softening in the plastic zone.

\section{State of the problem}

The effect of large loads and aggressive working environments (containing hydrogen sulfide, mercaptans), penetrating into the volume of structural elements, leads to their damage [3, 4]. The effect on the strength of the material of an individual crack or the final system of cracks in the framework of the linear theory of elasticity is the subject of linear fracture mechanics [5]. Nonlinear fracture mechanics [6] involves the analysis of the criteria and properties of material ductility in the vicinity of the tip of a single crack. Corrosion damage to the contact zone of the element material under high stress and corrosive environment leads to the appearance of many defects and microcracks, the account of the overall impact of which is not possible in the framework of fracture mechanics. Mathematical models and criteria describing the occurrence and development of scattered microdamages are formulated mainly within the framework of continuum mechanics [7]. Different types of corrosion affect on different parameters of metal structures. For example, the general mechanochemical continuous corrosion of metals leads to a loss of weight and volume of the material without significant loss of its strength [8]. The calculation of the decrease in the wall thickness of a pipeline subject to general 
mechanochemical corrosion in the framework of the linear theory of elasticity is given in [9]. Moreover, the process of metal loss is significantly extended over time. In case of intergranular and transcrystalline corrosion, on the contrary, the mechanical properties of the metal change practically without loss of its weight [8]. The combined action of corrosion and static tensile stresses leads to a gradual decrease in the resistance to plastic deformation and a decrease in the plasticity limit in ductile metals, carbon and low alloy steels, and various alloys [10]. The decrease in the mechanical properties of the material during loading due to the accumulation of damage and defects can be taken into account in the framework of the plasticity theory of inhomogeneous bodies [11, 12, 13]. In [11, 12, 13], to take into account the accumulation of damage to the material, it was proposed to introduce a special softening function (radial inhomogeneity of strength characteristics) in the criteria used for plasticity of the material for axisymmetric and some plane problems. In [14], modified plasticity criteria were used, which can take into account the accumulation of material damage in the case of more complex boundary conditions under which plastic inhomogeneity should change in accordance with the change in the elastoplastic boundary. In this paper, this is exactly the approach taken.

\section{Solution of the problem}

\subsection{Basic assumptions and relationships}

The element of a thick-walled extended pipeline is in flat deformation conditions. Consider the cross section of a pipeline with an internal circuit $a_{0}+f_{1}(r, \theta)$ and an external circuit $1+f_{2}(r, \theta)$ in the polar coordinate system $r, \theta$. The material of the pipeline is considered perfectly elastic-plastic.

The equations of equilibrium of the pipeline have the form:

$$
\frac{\partial \sigma_{r}}{\partial r}+\frac{1}{r} \frac{\partial \tau_{r \theta}}{\partial \theta}+\frac{\sigma_{r}-\sigma_{\theta}}{r}=0, \quad \frac{\partial \tau_{r \theta}}{\partial r}+\frac{1}{r} \frac{\partial \sigma_{\theta}}{\partial \theta}+2 \frac{\tau_{r \theta}}{r}=0 .
$$

Here are $\sigma_{r}, \sigma_{\theta}, \tau_{r \theta}$ the components of the stress tensor. In the elastic region, Hooke's law is valid for a homogeneous, isotropic linearly elastic material:

$$
\varepsilon_{i j}=\frac{1}{E}\left((1+\mu) \sigma_{i j}-\mu \delta_{i j} \sigma_{k k}\right) .
$$

Where $\sigma_{i j}$ and $\varepsilon_{i j}$ are the components of the stress and strain tensors, $E$ - is the elastic modulus, $\mu$ - is the Poisson's ratio, $\delta_{i j}-$ is the Kronecker symbol.

As a condition for the transition of the material into a plastic state, we accept the TrescaSaint-Venant condition, which is widely used in the calculation of plastic deformable metal structures

$$
\left(\sigma_{\theta}-\sigma_{r}\right)^{2}+4 \tau_{r \theta}^{2}=4 K_{*}^{2}
$$

where $K_{*}$ is adhesion coefficient.

The material strength parameter $K_{*}$ in condition (2) characterizes the plastic inhomogeneity formed as a result of varying degrees of damage to the material due to the force-corrosion effect and distributed over the thickness of the plastic zone, similar to the outline of its boundary. At the boundary of the plastic zone, the value $K_{*}$ is constant: $K_{*}=K_{1}$. The value 
$K_{*}$ is a special softening function, depending on the coordinates $r, \theta$ and loading parameters $r_{0}, \delta[14]:$

$$
K_{*}=K_{*}\left(r, r_{0}, \theta, \delta\right)
$$

Here $r_{0}, \delta$ - is the axisymmetric and nonaxisymmetric loading parameters: $r_{0}=r_{0}\left(P_{0}, P_{1}+\right.$ $\left.P_{2}\right), \delta=\delta\left(P_{1}-P_{2}\right)$.

The problem is solved by the method of joint use of static and physical equations for the considered elastoplastic material. In the non-axisymmetric formulation, the perturbation method is applied [15]. The solution is searched for in the form of series by degrees of a small parameter, which is the parameter $\delta$

$$
\begin{aligned}
& \sigma_{i j}=\sum_{0}^{\nu} \delta^{\nu} \sigma_{i j}^{(\nu)}=\sigma_{i j}^{0}+\sum_{1}^{\nu} \delta^{\nu} \sigma_{i j}^{(\nu)}, \quad K_{*}=\sum_{0}^{\nu} \delta^{\nu} K_{*}^{(\nu)}=K_{*}^{0}+\sum_{1}^{\nu} \delta^{\nu} K_{*}^{(\nu)}, \\
& r_{s}=\sum_{0}^{\nu} \delta^{\nu} r_{\nu}=r_{0}+\sum_{1}^{\nu} \delta^{\nu} r_{\nu}
\end{aligned}
$$

where $r_{s}$ is the desired elastoplastic boundary.

Linearizing equations (1), (3) and introducing, according to (1), the stress function $F=$ $F(r, \theta)$

$$
\sigma_{r}^{(\nu)}=\frac{1}{r} \frac{\partial F^{(\nu)}}{\partial r}+\frac{1}{r^{2}} \frac{\partial^{2} F^{(\nu)}}{\partial \theta^{2}}, \quad \sigma_{\theta}^{(\nu)}=\frac{\partial^{2} F^{(\nu)}}{\partial r^{2}}, \quad \tau_{r \theta}^{(\nu)}=-\frac{\partial}{\partial r}\left(\frac{1}{r} \frac{\partial F^{(\nu)}}{\partial \theta}\right), \quad \nu=0,1,2, \ldots
$$

we obtain in the plastic zone an inhomogeneous partial differential equation for the function $F^{(\nu)}(r, \theta)$ :

$$
r^{2} \frac{\partial^{2} F^{(\nu)}}{\partial r^{2}}-r \frac{\partial F^{(\nu)}}{\partial r}-\frac{\partial^{2} F^{(\nu)}}{\partial \theta^{2}}=r^{2} f^{(\nu)}(r, \theta), \quad \nu \geq 0
$$

where $f^{(\nu)}$ is the right side of the corresponding linearized relation:

$$
f^{0}=2 K_{*}^{0}, \quad f^{(I)}=2 K_{*}^{(I)}, \quad f^{(I I)}=-\frac{1}{K_{0}}\left(\tau_{r \theta}^{(I)}\right)^{2}+2 K_{*}^{(I I)} .
$$

The solution of equation $(7) F^{(\nu)}$ is determined taking into account static or geometric boundary conditions.

In the elastic region, the stress function $\Phi(r, \theta)$ satisfies the biharmonic equation $\left(\nabla^{2}\right.$ is the Laplace operator)

$$
\nabla^{2} \nabla^{2} \Phi=0
$$

The solution of equation (8) with $r, m \theta$ can be represented as

$$
\Phi_{m}=\left(C_{1} r^{m}+C_{2} r^{-m}+C_{3} r^{m+2}+C_{4} \varphi_{m}(r)\right) \cos m \theta, \quad m=0,1,2, \ldots,
$$

where $\varphi_{m}(r)=r^{m} \ln r$ at $m=0,1 ; \varphi_{m}(r)=r^{-m+2}$ at $m \geq 2$. Constants $C_{1}-C_{4}$ are found from the boundary conditions. 


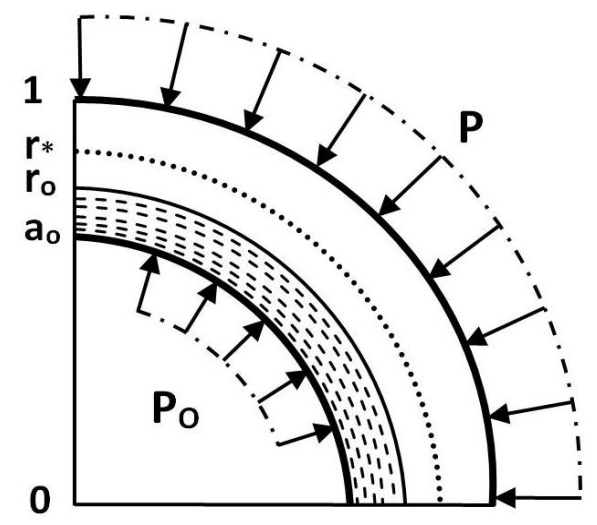

Figure 1: Design scheme for a thick-walled pipe element in an axisymmetric setting

\subsection{Thick-walled element in an axisymmetric setting}

First, find the axisymmetric state of the pipeline element. The axisymmetric problem for a thick-walled element is known in elasticity theory as the Lame problem. Assuming in the initial equations $\tau_{r \theta}^{0}=0, \partial \sigma_{i j}^{0} / \partial \theta=0, \partial K_{*}^{0} / \partial \theta=0, \delta=0$ we obtain the Lame problem in the accepted formulation (Fig. 1).

The axisymmetric boundary conditions on the internal and external contour of $a_{0}$ and 1 and the conjugation conditions on the contour of $r_{0}$ have the form (square (round) brackets at the indices mean belonging to the plastic (elastic) zon

$$
\begin{aligned}
& \sigma_{[r]}^{0}=P_{0} \text { at } r=a_{0} ; \sigma_{(r)}^{0}=P \text { at } r=1 ; \\
& {\left[\sigma_{r}^{0}\right]=\left[\sigma_{\theta}^{0}\right]=0 \text { at } r=r_{0},}
\end{aligned}
$$

Here big $[\ldots]$ brackets means a jump of a given value when crossing through the specifical boundary.

In the axisymmetric (zero) state of a thick-walled element, the softening function in the plastic zone $K_{*}^{0}$ depends on the current radius $r$ and the boundary radius $r_{0}$

$$
K_{*}^{0}=K_{*}\left(r, r_{0}\right)=\left(K_{0}-K_{1}\right) \bar{f}\left(r, r_{0}\right)+K_{1}
$$

Where $K_{0}$ and $K_{1}$ is the value of the strength of the material on the inner contour of the element and on the elastic-plastic radius $r_{0}, \bar{f}\left(r, r_{0}\right)$ - some core with properties $\bar{f}\left(a_{0}, 1\right)=1$, $\bar{f}\left(r_{0}, r_{0}\right)=0$. Such properties of the core allow us to describe the decrease in the value $H_{*}^{0}$ not only by the radius, but also depending on the position of the boundary radius $r_{0}$. As a core $\bar{f}\left(r, r_{0}\right)$, one can take the core [12], which well describes the softening of the material during loading (Fig. 2). It has the form $\bar{f}\left(r, r_{0}\right)=\frac{a_{0}^{n}\left(r_{0}^{n}-r^{n}\right)}{r^{n}\left(1-a_{0}^{n}\right)}(n-$ nonlinearity parameter).

Using equilibrium equations (1), plasticity condition (3), and also axisymmetric boundary conditions and conjugation conditions (10) we find all stress components and the radius of 


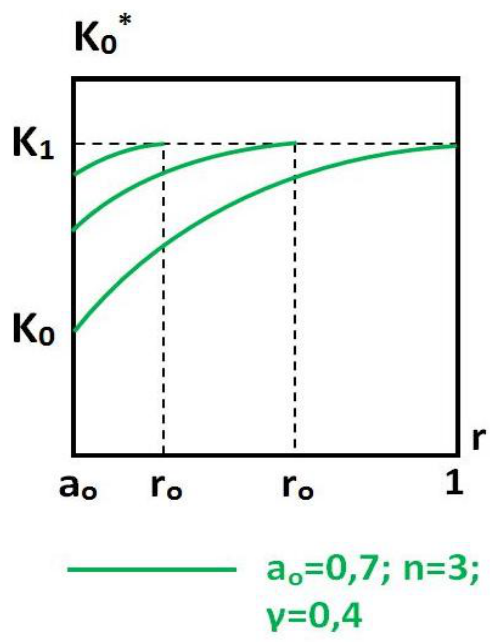

Figure 2: Decrease in the strength parameter $K_{*}^{0}$ depending on the position of the elastoplastic radius $r_{0}$ according to the presented softening function $K_{*}\left(r, r_{0}\right)$

the plastic zone $r_{0}$.

$$
\begin{aligned}
& \sigma_{[r]}^{0}=P_{0}+2 \int_{a_{0}}^{r_{0}} r^{-1} K_{*}^{0} d r, \quad \sigma_{[\theta]}^{0}=\sigma_{[r]}^{0}+2 K_{*}^{0}, \quad \tau_{[r \theta]}^{0}=0 \\
& \left.\begin{array}{l}
\sigma_{(r)}^{0} \\
\sigma_{(\theta)}^{0}
\end{array}\right\}=P+K_{1} r_{0}^{2}\left(1 \mp \frac{1}{r^{2}}\right), \quad \tau_{(r \theta)}^{0}=0
\end{aligned}
$$

The radius $r_{0}$ is implicitly determined from the equation

$$
P_{0}-P+2 \int_{a_{0}}^{r_{0}} r^{-1} K_{*}^{0} d r+K_{1}\left(1-r_{0}^{2}\right)=0
$$

In the absence of corrosion damage, the parameter $K_{*}^{0}=K_{1}$ and radius of the plastic zone $r_{0}$ are found from the equation

$$
P_{0}-P+2 K_{1}\left(\ln \left(\frac{r_{0}}{a_{0}}\right)+\frac{1}{2}\left(1-r_{0}^{2}\right)\right)=0
$$

Numerical calculations were performed using formulas (11) - (14) with the following data: $\mu=0,34 ; E=110 G P a ; \Delta P=P-P_{0} ; E=3667 K_{1}$. According to numerical results, the presence of corrosion damage affects the elastic-plastic state of the thick-walled element. The greatest interest is the relationship $\Delta P=\Delta P\left(r_{0}\right)$ between value of uniform pressure $\Delta P$ and the radius of the plastic zone $r_{0}$ (Fig. 3). This dependence is determined by the thickness parameter $a_{0}$ and the softening parameters of the material $n, \gamma=K_{0} / K_{1}$. From 


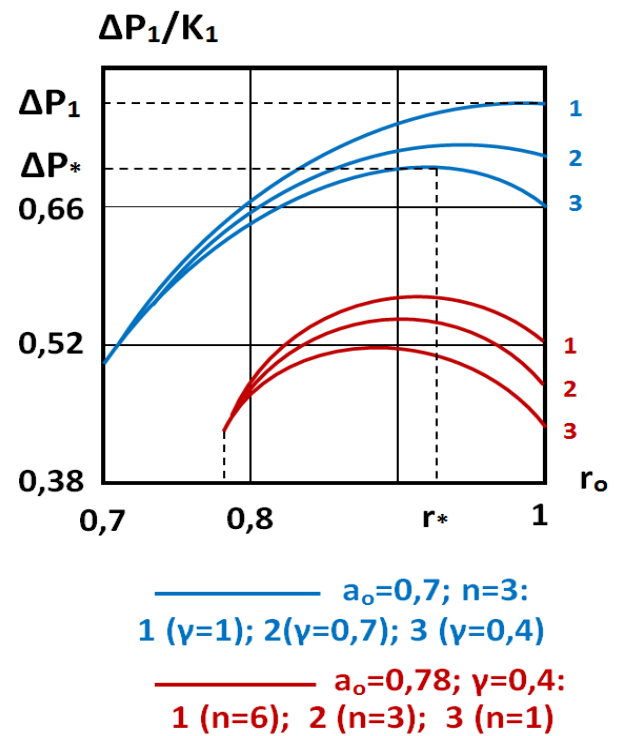

Figure 3: The relationship between the value of uniform pressure $\Delta P$ and the radius of the plastic zone $r_{0}$ for various thickness parameters and softening parameters of the material $n$, $\gamma=K_{0} / K_{1}$

the calculations it follows that the presence of corrosion damage $(\gamma<1)$ leads to an increase in radius $r_{0}$. Moreover, all curves with $\gamma<1$ have one maximum point with an abscissa $r_{0}=r_{*}$, where $a_{0}<r_{*}<1$. In the absence of damage $(\gamma=1)$, the radius $r_{*}=1$. The existence and uniqueness of maximum points follows analytically from the nonmonotonicity and convexity of the function $\Delta P=\Delta P\left(r_{0}\right)$.

The maximum point characterizes the moment of loss of the bearing capacity of a thickwalled element. Corresponding to the maximum point, pressure $\Delta P_{*}\left(\Delta P_{*} \leq \Delta P\right)$ and radius $r_{*}\left(r_{*} \leq 1\right)$ are limiting for the destruction of a thick-walled element. The value $r_{*}$ depends significantly on the thickness parameter $a_{0}$ : in a thinner element, it is located closer to the inner surface (Fig. 3). The obtained results can serve as an explanation of the phenomenon of premature failure of structural elements with corrosion damage.

We denote the relationship between external loads $P, P_{0}$ and radius $r_{0}$ as $g\left(P, P_{0}, r_{0}\right)=0$. Then the existence of a maximum point on the interval $a_{0}<r_{0}<1$ is expressed as an additional equation $\partial g\left(P, P_{0}, r_{0}\right) / \partial r_{0}=0$, which has the form: $K_{*}\left(a_{0}, r_{0}\right)-K_{1} r_{0}^{2}=0$.

The bearing capacity of a thick-walled element is determined as follows. From the two transcendental equations $g=0, \partial g / \partial r_{0}=0$, we first find the critical radius $r_{*}$, and then the critical loads at which the thick-walled element is destroyed.

With the known softening parameters and given external loads, it is possible to establish the optimal (minimum permissible) thickness parameter $a_{0}$ for a thick-walled element of two equations $g=0, \partial g / \partial r_{0}=0$. Calculations show that the bearing capacity of the element is significantly reduced in the presence of corrosion damage, for example, when the thickness $d=1-a_{0}=0,4$ is reduced by $12-15 \%$. The bearing capacity of an element that allows only elastic deformation is lower by $34-50 \%$ in comparison with elastoplastic elements. It follows 
from the calculations that the bearing capacity of the elements increases most effectively when their thickness increases only to $d=0.4 \div 0.5$.

\subsection{Thick-walled element in a non-axisymmetric setting (outward pressure uneven in contour)}

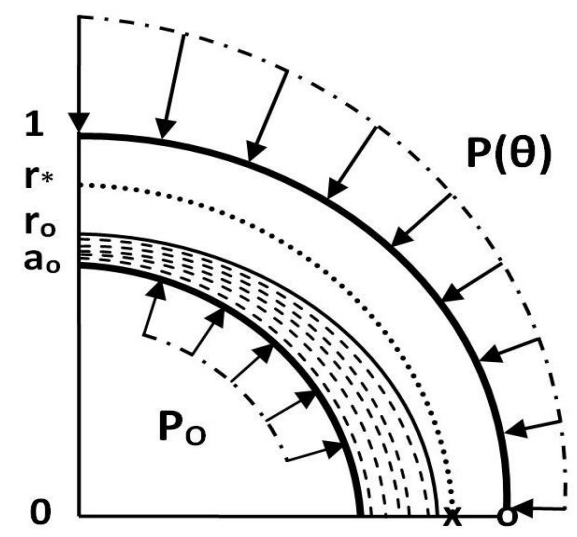

Figure 4: Design scheme for a thick-walled pipe element in a non-axisymmetric setting

Consider an extended thick-walled element loaded with an external pressure that is not uniform along the contour $P(\theta)$. The cross section of an element with an inner radius $a_{0}$ and an outer radius of 1 is in plane deformation (Fig. 4).

External pressure is elliptically distributed along the contour and can be written as

$$
P(\theta)=P[1-\delta \cos 2 \theta]
$$

where $P=\left(P_{\max }+P_{\min }\right) / 2$ is the averaged uniform pressure, $\delta=\left(P_{\max }-P_{\min }\right) /\left(P_{\max }+P_{\min }\right)$ - a parameter characterizing the deviation of external pressure from uniform.

The solution is sought in the form (5) at $\nu \geq 0$. The zero solution for $\nu=0$ was found in the previous part of the paper. Find a solution at $\nu=1$. The function $F^{(1)}$ in $(7)$ is represented based on the static boundary conditions (15) on the outer contour of the element: $F^{(1)}=R(r) \cos 2 \theta$.

Solving (7), we find the function $F^{(I)}$ in the plastic zone:

$$
F^{(I)}=\left(A_{i} R_{i}+R_{i} \int_{a_{0}}^{r} \frac{\nu_{i}(r)}{\nu(r)} d r\right) \cos 2 \theta, \quad i=\overline{1,2}
$$

where $A_{i} R_{i}=A_{1} R_{1}+A_{2} R_{2}=r\left(A_{1} \cos (\sqrt{3} \ln r)+A_{2} \sin (\sqrt{3} \ln r), V(r)\right.$ - is the Wronskian of the solution system $R_{i}, V_{i}(r)$ is the determinant obtained from the determinant $V(r)$ by replacing the $i$-th column with a column with a single nonzero element $2 K_{*}^{(I)} \cos ^{-1} 2 \theta$ located at its end. 
Using (6), (16) we find the stress components in the plastic zone. They must satisfy the linearized boundary conditions on the inner contour

$$
\sigma_{[r]}^{(I)}=0, \quad \tau_{[r \theta]}^{(I)}=0 \text { at } r=a_{0} .
$$

The components $\sigma_{[r]}^{(I)}, \sigma_{[\theta]}^{(I)}, \tau_{[r \theta]}^{(I)}$ of the stress tensor in the elastic region of the cylinder are determined from (6), (9). They satisfy the given static boundary conditions on the external contour (15) and two linearized conditions of stress conjugation $\sigma_{r}$ and $\tau_{\gamma \theta}$ on the boundary of the plastic zone:

$$
\left[\sigma_{[r]}^{(I)}\right]=0, \quad\left[\tau_{[r \theta]}^{(I)}\right]=0 \quad \text { at } r=r_{0} .
$$

As a result, we obtain the boundary-value problem for an elastic ring of radius $r_{0}$ and 1 under the following boundary conditions:

$$
\begin{gathered}
\sigma_{[r]}^{(I)}=N_{1}(r) \cos 2 \theta, \quad \tau_{[r \theta]}^{(I)}=N_{2}(r) \sin 2 \theta \text { at } r=r_{0}, \\
\sigma_{[r]}^{(I)}=-P \cos 2 \theta, \quad \tau_{[r \theta]}^{(I)}=0 \quad \text { at } r=1 .
\end{gathered}
$$

Solving this problem, we find the stress components in the elastic region.

The equation of the boundary of the plastic zone $r_{s}$ is sought in the form $r_{s}=r_{0}+\delta r_{1}$. To determine the value of $r_{1}$, we use the linearized conditions for the conjugation of the components $\sigma_{\theta}$ and $K_{*}$ on $r_{0}$ :

$$
\left[\sigma_{[\theta]}^{(I)}+\frac{d \sigma_{\theta}^{0}}{d r} r_{1}\right]=0, \quad\left[K_{*}^{(I)}+\frac{d K_{*}^{0}}{d r} r_{1}\right]=0 \text { at } r=r_{0}
$$

where will we get it

$$
r_{1}=\left(\sigma_{\theta}^{(I)}-\sigma_{[\theta]}^{(I)}\right) /\left(\frac{d \sigma_{[\theta]}^{0}}{d r}-\frac{d \sigma_{(\theta)}^{0}}{d r}\right), \quad K_{*}^{(I)}=-\frac{d K_{*}^{0}}{d r} r_{1} \text { at } r=r_{0} .
$$

Then for $r_{1}$ we will have $r_{1}=\varphi\left(r_{0}\right) r_{0} \cos 2 \theta$, where $\varphi\left(r_{0}\right)$ is a function of $r_{0}$ :

$$
\begin{gathered}
\varphi\left(r_{0}\right)=\frac{X_{0}}{X_{1}+X_{2}+Z}, \quad X_{0}=4\left(1-r_{0}^{2}+r_{0}^{-2}-r_{0}^{4}\right) \frac{-P}{N}, \\
N=6-4\left(r_{0}^{2}+r_{0}^{-2}\right)+r_{0}^{4}+r_{0}^{-4}, \quad A=\frac{1}{2}\left(12+12 \alpha_{2}-\alpha_{2}^{2}\right)^{1 / 2}, \\
X_{1}=\left(10-4 r_{0}^{2}-4 r_{0}^{-2}-r_{0}^{4}-r_{0}^{-4}+\alpha_{1} N\right) \frac{\bar{K}_{*}}{N} \times \\
\times\left[\left(\sqrt{3} \cos \left(\sqrt{3} \ln r_{0}\right)+\sin \left(\sqrt{3} \ln r_{0}\right)\right) B_{1}+\left(\cos \left(\sqrt{3} \ln r_{0}\right)-\sqrt{3} \sin \left(\sqrt{3} \ln r_{0}\right)\right) B_{2}\right], \\
X_{2}=-2\left(4-4 r_{0}^{2}+r_{0}^{4}-r_{0}^{-4}\right) \frac{\bar{K}_{*}}{N} \times\left(\sin \left(\sqrt{3} \ln r_{0}\right) B_{1}+\cos \left(\sqrt{3} \ln r_{0}\right) B_{2}\right), \\
Z=4 K_{1}, \quad \bar{K}_{*}=\left(K_{0}-K_{1}\right) \frac{a_{0}^{n}}{1-a_{0}^{n}} \frac{n}{r_{0}}, \quad B_{1}=\frac{r_{0}}{2} \sin \left(\sqrt{3} \ln r_{0}-\frac{\pi}{3}\right)-\frac{a_{0}}{2} \sin \left(\sqrt{3} \ln r_{0}-\frac{\pi}{3}\right),
\end{gathered}
$$




$$
B_{2}=\frac{r_{0}}{2} \cos \left(\sqrt{3} \ln r_{0}-\frac{\pi}{3}\right)-\frac{a_{0}}{2} \cos \left(\sqrt{3} \ln r_{0}-\frac{\pi}{3}\right)
$$

In the homogeneous case we have: $X_{0}$ - the same thing, $X_{1}=X_{2}=0, H_{*}^{0}=H_{1}, H_{*}^{(I)}=0$

$$
X_{1}=X_{2}=0, \quad K_{*}^{0}=K_{1}, \quad K_{*}^{(I)}=0, \quad Z=4 K_{1}
$$

Moreover, the radius $r_{0}$ corresponds to the homogeneous case.

The equation of the boundary of the plastic zone $r_{s}$ takes the form:

$$
r_{s}=r_{0}\left(1+\delta \varphi\left(r_{0}\right) \cos 2 \theta\right)
$$

The solution exists under the condition $r_{0}\left(1-\delta \varphi\left(r_{0}\right)\right) \geq a_{0}$.

The bearing capacity of a thick-walled element can be determined from the transcendental equation

$$
r_{*}=r_{0}\left(1+\delta \varphi\left(r_{0}\right)\right)
$$

First, from (20) we find the radius $r_{0}$. Substituting the found radius $r_{0}$ into equation (13), we obtain critical loads at which the plastic zone reaches some "critical" points of the thick-walled element.

In the absence of corrosion damage to the element, $r_{*}=1$ should be taken in equation (20) and equation (14) should be used. The critical points in this case (marked with zeros in Fig. 4) are on the external contour of the element in the directions of the minimum external pressure $P_{\text {min }}$. In the presence of corrosion damage to the element, the critical points (marked with crosses in Fig. 4) are inside the element on circuit $r_{*}$ in the same directions. Reaching these crosses with at least one point of the plastic zone will lead to the destruction of the element. As can be seen from Figure 4, the plastic zone is elongated in the directions of action of $P_{\min }$. Damage to the material leads to an increase in the size of the plastic zone. The degree of damage to the material depends on the size of this zone. The element has the greatest damage in the directions of action of $P_{\min }$. Therefore, the softening of the element depends both on the size of the plastic zone and on the orientation of its boundary.

\section{Conclusion}

The stress-strain state of an elastoplastic element of a thick-walled pipeline is studied under conditions of force and corrosion using a special softening function (plastic inhomogeneity) in the plasticity condition of Tresca-Saint-Venant.

The elastoplastic problem for a thick-walled element in an axisymmetric formulation (with uniform external and internal pressure) and non-axisymmetric formulation (with an external pressure uneven in contour) is considered. The problems are solved by the method of sharing static and physical equations and the perturbation method in the theory of an elastoplastic body.

An assessment of the strength and bearing capacity of a thick-walled element under corrosive force is given. 


\section{References}

[1] СНиП 3.05-01-2010. "Magistral'nye truboprovody [Trunk pipelines]".

[2] CП 33.13330.2012. "Raschet na prochnost' stal'nyh truboprovodov [Strength analysis of steel pipelines]".

[3] Gareev A.G., Nasibullina O.A. and Rizvanov R.G., "Izuchenie korrozionnogo rastreskivaniya magistral'nyh gazonefteprovodov [The study of corrosion cracking of gas and oil pipelines]", Oil and gas business 6 (2012), http://www.ogbus.ru/ authors/Gareev2.pdf.

[4] Basiyev K.D. et al., "Issledovanie processov zarozhdeniya i razvitiya korrozionno-mekhanicheskih treshchin na poverhnosti trub [Study of the processes of nucleation and development of corrosion-mechanical cracks on the surface of pipes]" , Bulletin of the Vladikavkaz Scientific Center 3 (2014): 56-61.

[5] Cherepanov G.P., Mekhanika hrupkogo razrusheniya [Mechanics of brittle fracture] (Moscow: Science, 1974): 640.

[6] Astafiev V.I., Radayev U.N. and Stepanova L.V., Nelinejnaya mekhanika razrusheniya [Nonlinear fracture mechanics] (Samara: SamSU Publishing House, 2001): 562.

[7] Sadyrin A.I., "Modeli nakopleniya povrezhdenij i kriterii razrusheniya konstrukcionnyh uprugoplasticheskih materialov pri dinamicheskom nagruzhenii [Damage accumulation models and fracture criteria of structural elastoplastic materials under dynamic loading]", Problems of strength and plasticity 74 (2012): 28-39.

[8] Rossina N.G. et al., Korroziya i zashchita metallov. CHast'1. Metody issledovanij korrozionnyh processov [Corrosion and metal protection. Part 1. Research methods for corrosion processes] (Ekaterinburg: Ural University Publishing House, 2019): 108.

[9] Kushrin S.Ya., Mosyagin M.N. and Pesin A.S., Processy razvitiya korrozionnyh treshchin pod napryazheniem magistral'nyh gazoprovodov pod vliyaniem izmeneniya ih vysotnogo polozheniya i katodnoj zashchity [Processes of development of corrosion cracks under stress of main gas pipelines under the influence of changes in their altitude position and cathodic protection] (St.Petersburg: Nedra, 2010): 168.

[10] Ovchinnikov I.I., "Issledovanie povedeniya obolochechnyh konstrukcij, ekspluatiruyushchihsya v sredah, vyzyvayushchih korrozionnoe rastreskivanie [Study of the behavior of shell structures operating in environments that cause corrosion cracking]", Science 4 (2012): 1-30.

[11] Alimzhanov M.T., "Uprugoplasticheskaya zadacha, uchityvayushchaya neodnorodnost' mekhanicheskih svojstv materiala [Elastic-plastic problem, taking into account the heterogeneity of the mechanical properties of the material]" , Reports of the USSR Academy of Sciences 6 (1978): 1281-1284.

[12] Alimzhanov M.T., "O nakoplenii povrezhdenij i nesushchej sposobnosti elementov tolstostennyh konstrukcij [On the accumulation of damage and bearing capacity of elements of thick-walled structures]", International journal Problems of mechanical engineering and automation 1 (1992): 58-64.

[13] Alimzhanov A.M., "Dvumernaya uprugoplasticheskaya zadacha s lokal'noj plasticheskoj neodnorodnost'yu [Twodimensional elastic-plastic problem from the local plastic inhomogeneity]", Mechanics and modeling of technology processes 1 (1997): 3-17.

[14] Alimzhanov A.M., "Ploskaya uprugoplasticheskaya zadacha dlya neodnorodnogo tela s otverstiem [Flat elastic-plastic problem for a non-uniform body with a hole]", Bulletin of the Russian Academy of Sciences. Mechanics of solids 2 (1998): 119-138.

[15] Ivlev D.D. and Ershov L.V., Metod vozmushchenij v teorii uprugoplasticheskogo tela [The perturbation method in the theory of an elastoplastic body] (Moscow: Science, 1978). 